\title{
Pengaruh Parenting Self Efficacy terhadap Keterlibatan Orang Tua dalam Karier Remaja
}

\author{
AI NURYANTI SAFITRI \& DEWI RETNO SUMINAR* \\ Departemen Psikologi Pendidikan dan Perkembangan, Fakultas Psikologi Universitas Airlangga
}

\begin{abstract}
ABSTRAK
Penelitian ini bertujuan untuk menguji pengaruh parenting self efficacy terhadap keterlibatan orang tua dalam karier remaja. Parenting self efficacy adalah penilaian orang tua terhadap kompetensi atau kemampuan mereka untuk secara positif mempengaruhi perilaku dan perkembangan anak mereka. Keterlibatan orang tua terkait dengan karier anak diistilahkan sebagai parental career related behavior yang berarti segala perilau orng tua dalam membimbing serta memberikan pertimbangan terkait karier anak. Partisipan penelitian berjumlah 84 orang tua yang memiliki anak seorang remaja dengan rentang usia 15 sampai 24 tahun. Penelitian ini menggunakan metode kuantitatif dan teknik survei untuk pengambilan data. Analisis data menggunakan analisis regresi linear sederhana dengan menggunakan bantuan perangkat SPPSS 25.0 for windows. Berdasarkan hasil analisis data penelitian diketahui bahwa parenting self efficacy secara signifikan berpengaruh positif terhadap keterlibatan orang tua dalam karier remaja sebesar 34,9 persen dan persamaan garis regresi $Y=5,563+0,131 \mathrm{X}$.
\end{abstract}

Kata kunci: keterlibatan orang tua dalam karier, parenting self efficacy

\begin{abstract}
This study aims to examine the effect of parenting self-efficacy on parental involvement in adolescent careers. Parenting self-efficacyis a parent's assessment of their competence or ability to positively influence the behavior and development of their children. Parental involvement related to a child's career is defined by parental career-related behavior, which means all the behavior of the parents in guiding and giving considerations related to the child's career. The study participants were 84 parents who have children of a teenager aged 15 to 24 years. This study uses quantitative methods and survey techniques for data collection. Data analysis used simple linear regression analysis using SPSS 25.0 for windows. Based on the results of the research data analysis, it is known that parenting self-efficacy has a significant positive effect on parental involvement in adolescent careers by 34.9 percent and the regression line equation $Y=5.563+0.131 X$.
\end{abstract}

Keywords: involvement of parents in careers, parenting self efficacy

Buletin Penelitian Psikologi dan Kesehatan Mental (BRPKM), 2021, Vol. 1(1), 27-36

*Alamat korespondensi: Fakultas Psikologi Universitas Airlangga, Kampus B Universitas Airlangga Jalan Airlangga 4-6 Surabaya 60286. Surel: dewi.suminar@psikologi.unair.ac.id

Naskah ini merupakan naskah dengan akses terbuka dibawah ketentuan the Creative Common Attribution License (CC-BY-4.0) (http://creativecommons.org/licenses/by/4.0), sehingga penggunaan, distribusi, reproduksi dalam media apapun atas artikel ini tidak dibatasi, selama sumber aslinya disitir dengan baik. 


\section{P E N D A H U L U A N}

Pendidikan merupakan ranah yang sangat penting bagi generasi muda dalam menyongsong masa depan. Tidak hanya membentuk individu menjadi lebih baik, pendidikan juga diharapkan dapat menghasilkan generasi penerus bangsa yang sukses dan membanggakan. Gagasan mengenai pendidikan memang tidak pernah ada habisnya untuk dibahas, harapannya dapat memberi solusi kearah yang lebih baik guna menghadapi tuntutan zaman. Pendidikan juga memiliki peranan yang sangat penting dalam mendorong keberhasilan kerja atau karier individu. Sebab, salah satu aspek penting dalam kehidupan yaitu memiliki karier yang memuaskan.

Upaya pertama memiliki karier yang memuaskan adalah mengidentifikasi dan mencari informasi sebanyak mungkin tentang minat dan kemampuan yang dimiliki oleh masing-masing individu. Upaya tersebut idealnya dilakukan pada saat individu berada pada usia remaja. Menurut Super (1980) remaja berada pada tahap eksplorasi yang ditandai dengan mempersiapkan karier yang akan diambil berdasarkan minat dan bakatnya. Remaja membutuhkan keterlibatan dari berbagai pihak, salah satunya sekolah dan keluarga, dalam memenuhi tugas pada tahap perkembangan tersebut. Sekolah maupun perguruan tinggi menyediakan layanan informasi dan bimbingan terkait karier, pekerjaan, pemilihan jurusan atau studi lanjut, serta pengembangan minat dan bakat. Layanan informasi dan konsultasi yang disediakan oleh sekolah dapat memberi arah pilihan karier sesuai dengan potensi atau kemampuan yang dimiliki oleh remaja tersebut.

Pihak selanjutnya yang seharusnya terlibat dalam karier remaja adalah keluarga, khususnya orang tua. Orang tua merupakan pihak utama yang memberikan pengaruh paling penting dalam karier remaja. Hal tersebut sejalan dengan penelitian Witko (2005) bahwa pihak pertama yang terlibat dalam mendukung karier anak adalah orang tua diikuti tokoh karier, teman, konselor sekolah, guru, orang yang dipercaya, wali kelas, dan lainnya (Putra, 2018). Otto (2000) mengungkapkan bahwa remaja sering kali mendatangi orang tua untuk berdiskusi tentang kariernya, selanjutnya Mortimer, dkk (2002) mengatakan bahwa orang tua sebagai pengaruh utama dalam transisi pendidikan dan karier (Dietrich \& Kracke, 2009).

Keterlibatan orang tua dalam karier disebut juga parental career related behavior, yaitu perilaku orang tua dalam membimbing dan memberikan pertimbangan karier untuk anaknya. Keterlibatan orang tua dalam karier tersebut ditandai dengan perilaku aktif untuk melibatkan diri mereka yang memiliki pengaruh langsung dalam aktivitas karier anak (Joseph, 2012). Perilaku orang tua yang dapat dikatakan terlibat dalam karier anak ditunjukan dengan beberapa macam upaya, seperti menyediakan informasi terkait karier, membantu anak dalam eksplorasi karier, dan memberi arahan terkait karier (Joseph, 2012). Beberapa upaya tersebut bisa dilakukan oleh orang tua dengan cara bekerja sama dengan pihak sekolah. Orang tua dapat menggunakan informasi mengenai kemampuan, potensi, minat, bakat serta kelebihan dan kekurangan remaja dalam memberi arah pilihan karier. Orang tua juga dituntut untuk memberi layanan bimbingan atau konsultasi terkait karier selama di rumah, sebab hal tersebut merupakan bagian dari peran dan tanggung jawab orang tua sebagai model dan konselor bagi karier remaja.

Keterlibatan dalam karier yang diberikan oleh orang tua sangat penting dalam membantu remaja mencapai karier di masa depan. Remaja akan terbantu dalam merencanakan dan memutuskan arah pilihan karier sesuai dengan minat dan kemampuannya. Hal ini sesuai dengan penelitian Dietrich dan Kracke yang mengungkapkan bahwa orang tua yang terlibat serta mendukung karier dapat membantu

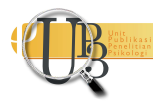


remaja dalam mengeksplorasi kariernya (Dietrich \& Kracke, 2009). Mengingat pentingnya keterlibatan orang tua dalam karier remaja, masih banyak orang tua yang tidak menjalankan tugasnya tersebut. Hasil observasi Wulandari (2017) pada beberapa orang tua di Jorong Rimbo Tangah Kecamatan Sangir, dalam setahun terakhir orang tua tidak melalukan analisis terkait informasi dari sekolah tentang minat dan kemampuan yang dimiliki oleh anak, tidak memberikan informasi tentang usaha yang diperlukan dalam mencapai karier, studi lanjutan, dan pekerjaan yang dipilih dan diinginkan oleh anak, serta tidak mendiskusikan risiko dan keuntungan ketika anak menetapkan pilihan karier tertentu. Menteri Keuangan Sri Mulyani juga pernah mengatakan hal yang sama, bahwa 80\% orang tua tidak pernah memberi masukan dalam pendidikan dan karier anak (Setiawan, 2017).

Orang tua yang tidak terlibat dalam karier remaja dapat berdampak pada remaja bahkan orang tua itu sendiri. Remaja cenderung tidak tahu dan menghindar dalam memulai tindakan yang behubungan dengan karier, serta sulit menentukan aktivitas pengembangan diri yang menunjang kariernya di masa depan. Pada orang tua, dampak yang mungkin timbul adalah tidak terealisasikannya peran dan tanggung jawab yang seharusnya dilakukan oleh orang tua serta tidak terpenuhinya tugas-tugas perkembangan sebagai orang tua. Pleck (1997) mengatakan bahwa orang tua yang tidak terlibat dalam karier anak, menandakan tidak matang secara sosial, orang tua tidak puas dengan kehidupan mereka (Eggebeen \& Knoester, 2001), tidak mampu memahami diri dan berempati dengan orang lain, serta tidak dapat mengelola emosi dengan baik (Hidayati, Kaloeti, \& Karyono, 2011; Harahap, 2016).

Seiring dengan pentingnya keterlibatan orang tua bagi karier remaja. Terlibat dalam karier anak juga merupakan sebuah keharusan bagi orang tua yang memiliki anak seorang remaja. Orang tua memiliki peran dan tanggung jawab dalam memenuhi segala kebutuhan yang diperlukan remaja dalam masa perkembangan kariernya. Hidayati (2010) yang juga mengatakan bahwa tugas orang tua tidak hanya sekedar memenuhi kebutuhan fisik, tetapi memenuhi kebutuhan materil, emosi, dan psikologis anak dan memberikan kesempatan seluas-luasnya dalam menempuh pendidikan serta karier anak. Agar mampu menghadapi tantangan sebagai orang tua, seseorang juga membutuhkan self efficacy yang cukup. Menurut Ozer dan Bandura (1990) self efficacy berkaitan dengan motivasi, sumber daya kognitif, dan tindakan yang diperlukan untuk melakukan kontrol atas peristiwa diberikan. Pada orang tua, self efficacy yang dimaksud adalah parenting self efficacy. Parenting self efficacy didefinisikan sebagai penilaian orang tua terhadap kompetensi dirinya dalam peran sebagai orang tua atau persepsi orang tua tentang kemampuan mereka untuk secara positif mempengaruhi perilaku dan perkembangan anakanak mereka (Coleman \& Karraker, 2000).

Parenting self efficacy dibentuk oleh pengalaman keberhasilan yang dialami oleh orang tua (direct experience), pengalaman mengamati orang lain (vicarious experience), kondisi emosi (emotional state), dan umpan balik verbal dari orang lain (verbal persuasion) (Coleman, 1998). Menurut Bandura (1997) Verbal persuasion yang dimilliki oleh orang tua sangat penting dalam mendorong dan mendukung karier anak. Parenting self efficacy juga merupakan salah satu aspek yang mempengaruhi keterlibatan orang tua dalam karier. Dalam penelitian Putra (2018) mengungkapkan bahwa salah satu faktor keterlibatan orang tua dalam karier adalah parenting self efficacy. Hoover-Depsey dan Sandler (1995) mengungkapkan bahwa parenting self efficacy memiliki kontribusi yang paling signifikan terhadap keterlibatan orang tua dalam karier anak dibandingkan faktor lainnya. Namun dalam penelitian Grolnick, dkk (1997) dan Simon (2004) menunjukan bahwa status sosial ekonomi serta parenting self efficacy tidak berpengaruh terhadap keterlibatan orang tua dalam karier anak (Hoover-Dempsey, et al., 2005).

Kesimpulan dari beberapa penilitian tersebut, parenting self efficacy belum secara konsisten menunjukan pengaruh terhadap keterlibatan orang tua dalam karier. Oleh sebab itu, peneliti ingin

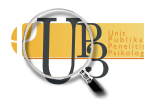


mengetahui pengaruh parenting self efficacy terhadap keterlibatan orang tua dalam karier remaja. Kelemahan dari penelitian ini adalah tidak membahas keterlibatan orang tua dalam karier secara meluas. Jika berbicara tentang karier, pembahasan tidak hanya sekedar pada persiapan atau pemilihan karier saja. Karier mencakup kemajuan dalam kehidupan, pendidikan, pekerjaan, dan jabatan yang prosesnya berlangsung sepanjang hidup. Adapun pada penelitian ini, keterlibatan orang tua dalam karier ditujukan pada remaja, dimana remaja menjadi tahap awal dalam perjalanan atau perkembangan karier manusia. Hipotesis dalam penelitian ini adalah parenting self efficacy berpengaruh terhadap keterlibatan orang tua dalam karier remaja.

\section{MET O D E}

\section{Desain Penelitian}

Jenis penelitian adalah penelitian eksplanasi atau biasa disebut explanatory research merupakan penelitian yang menjelaskan mengapa sesuatu terjadi serta menilai hubungan sebab akibat antar variabel melalui pengujian hipotesis (Sugiyono, 2013). Penelitian ini menggunakan pendekatan kuantitatif, menurut Azwar (2012) penelitian kuantiatif menekankan pada analisis menggunakan angka dan data-data numerik yang diolah dengan metode statistik. Tipe penelitian yang digunakan adalah survey. Neuman (2000) mengemukakan bahwa penelitian survei adalah teknik pengumpulan informasi yang dilakukan dengan cara menyusun daftar pertanyaan yang diajukan pada responden.

\section{Partisipan}

Populasi dalam penelitian ini adalah orang tua, baik ayah maupun ibu yang mempunyai anak seorang peserta didik di sekolah atau perguruan tinggi dan berusia 15 hingga 24 tahun. Teknik pengambilan sampel pada penelitian ini adalah non-probability sampling, yaitu teknik yang digunakan saat jumlah anggota dalam satu populasi tidak memiliki kesempatan yang sama untuk dipilih sebagai sampel penelitian. Penulis menggunakan teknik ini karena tidak adanya data yang pasti terkait partisipan penelitian yang dibutuhkan. Menurut Neuman (2000) teknik ini digunakan apabila peneliti tidak mengetahui seberapa jumlah populasi dari sampel yang akan diambil. Teknik sampling yang digunakan berupa purposive sampling, yaitu teknik yang menggunakan kriteria-kriteria tertentu dalam menentukan sampel yang hendak digunakan (Neuman, 2000).

\section{Data Deskriptif}

Pada penelitian ini, penulis menggunakan data deskriptif atau data demografis terkait usia partsipan. Penulis menggunakan 84 partisipan yang merupakan orang tua, baik ayah dan/atau ibu $\left(M_{\text {usia }}=47,13\right.$; $S D_{\text {usia }}=5,23 ; 63$ persen wanita atau seorang ibu) dan $\left(M_{\text {usia }}=49,77 ; S D_{\text {usia }}=6,85 ; 37\right.$ persen pria atau seorang ayah) yang memiliki anak dengan rentang usia 15 hingga 24 tahun dan merupakan peserta didik di sekolah maupun perguruan tinggi.

\section{Pengukuran}

Pengukuran pada setiap variabel penelitian dilakukan dengan menyebarkan kuesioner. Kuesioner adalah daftar pertanyaan terstruktur dengan alternatif jawaban yang telah tersedia sehingga responden hanya tinggal memilih jawaban sesuai dengan aspirasi, persepsi, sikap, keadaan, ataupun pendapat pribadinya (Suryanto, 1995). Kuesioner disajikan dalam bentuk online melalui google form. Adapun skala parenting self efficacy dikembangkan oleh Coleman dan Karraker (2000) dan didasarkan pada 5 aspek yakni achievement, nurturance, recreation, health, dan discipline (Coleman \& Karraker, 1997). Skala ini telah diadaptasi oleh Harahap (2016) dan telah diujicobakan pada 61 subjek. Skala keterlibatan Buletin Riset Psikologi dan Kesehatan Mental (BRPKM) 2021, Vol. 1(1), 27-36

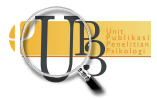


orang tua dalam karier didasarkan pada aspek yang dikemukakan oleh Dietrich dan Kracke (2009). Skala ini telah diadaptasi kedalam bahasa dan budaya Indonesia dan telah diujicobakan pada 413 responden (Anastiani \& Primana, 2019). Adapun skala pada penelitian ini menggunakan metode rating yang dijumlahkan (method of summated ratings) atau biasa disebut skala likert yang berorientasi pada respon (Azwar, 2004). Skala parenting self efficacy dan keterlibatan orang tua dalam karier terdiri atas aitem favorable dan unfavorable dengan 4 alternatif jawaban, yaitu "Sangat Tidak Sesuai", "Tidak Sesuai", "Sesuai", dan "Sangat Sesuai", dimana untuk pernyataan favorable yang jawabannya "Sangat Tidak Sesuai" akan diberi nilai terendah yaitu 1 dan jawaban "Sangat Sesuai" diberi nilai tertinggi yaitu 4. Adapun untuk pernyataan unfavorable sistem pembentukan nilainya adalah sebaliknya.

Alat ukur telah dilakukan validitas isi atau disebut content validity dengan menggunakan professional judgement. Penulis meminta kesediaan dosen-dosen Fakultas Psikologi Universitas Airlangga sebagai professional judgement untuk menjadi rater dalam penelitian ini. Skala parenting self efficacy yang dikembangkan oleh Coleman dan Karraker (2000) dan diadaptasi oleh Harahap (2016) juga telah diuji validitas dalam penelitiannya yang berjudul "Pengaruh Parenting self efficacy terhadap kepuasan perkawinan dan keterlibatan ayah dalam pengasuhan". Harahap (2016) menggunakan professional judgement yang merupakan Dosen Fakultas Psikologi Universitas Airlangga. Skala keterlibatan orang tua dalam karier yang dikembangkan oleh Dietrich dan Kracke (2009) dan diadaptasi oleh Anastiani dan Primana (2019) telah diuji validitas menggunakan professional judgement yang merupakan Dosen Fakultas Psikologi Universitas Indonesia.

Penulis melakukan uji asumsi diantaranya uji normalitas, uji linearitas, dan uji heteroskedastisitas. Hasil uji normalitas memiliki signifikansi sebesar 0,089, uji linearitas sebesar 0,000 dan uji heteroskedastisitas diperoleh hasil signifikansi sebesar 0,332. Uji asumsi dilakukan dengan bantuan program SPSS 25.0 for windows.

Pada penelitian ini, reliabilitas menggunakan rumus Cronbach Alpha $(\alpha)$. Variabel parenting self efficacy diukur menggunakan Self Efficacy For Parenting Task Index (SEPTI), yang terdiri dari 27 aitem dengan 4 pilihan jawaban (1="sangat tidak sesuai", 4="sangat sesuai), dengan nilai $(\alpha=0.925)$. Keterlibatan orang tua dalam karier diukur menggunakan parental career-related behavior (PCB) yang terdiri dari 5 aitem dengan 4 pilihan jawaban (1="sangat tidak sesuai", 4="sangat sesuai) dan didapatkan hasil $(\alpha=0.763)$.

\section{Analisis Data}

Penelitian ini bertujuan untuk menguji pengaruh parenting self efficacy terhadap keterlibatan orang tua dalam karier. Oleh karena itu, penulis menggunakan uji hipotesis dalam analisis regresi linear sederhana dan pengolahan data menggunakan program SPSS 25.0 for windows. Analisis regresi linear sederhana digunakan untuk mengetahui besarnya pengaruh variabel bebas (X) terhadap variabel tergantung (Y) (Sugiyono, 2013):

\section{H A S I L P E N EL I T I A N}

Jumlah subjek pada penelitian ini sebanyak 84 orang. Nilai minimum untuk variabel parenting self efficacy dan keterlibatan orang tua dalam karier secara berturut-turut adalah 59 dan 10, sedangkan untuk nilai maksimum adalah 112 dan 20. Nilai mean dan standar deviasi untuk variabel parenting self efficacy $(M=4.8, S D=7.8)$ dan keterlibatan orang tua dalam karier $(M=16.7, S D=1.73)$. Nilai Skewness/kecondongan parenting self efficacy adalah -1,098 dan keterlibatan orang tua dalam karier sebesar -0,336. Adapun nilai kurtosis/keruncingan parenting self efficacy adalah 4,007 dan keterlibatan orang tua dalam karier sebesar 1,998.

Buletin Riset Psikologi dan Kesehatan Mental (BRPKM)

2021, Vol. 1(1), 27-36 
Kategorisasi dalam penelitian ini membagi subjek menjadi tiga kategori, yaitu rendah, sedang, tinggi. Kategorisasi skala ini merupakan cara menginterpretasikan suatu skor hasil pengukuran psikologis dengan menggunakan suatu norma pembanding (Azwar, 2012). Hasil dari pengolahan data diperoleh nilai mean sebesar 85 dan standar deviasi sebesar 8 untuk variabel parenting self efficacy. Adapun partisipan dengan parenting self efficacy kategori sedang berjumlah 11 orang dan tinggi berjumlah 73 partisipan. Kemudian partisipan dengan keterlibatan orang tua dalam karier kategori sedang berjumlah 3 orang dan 81 orang berada dikategori tinggi.

Salah satu syarat dalam menggunakan teknik analisis regresi yaitu variasi residual memiliki variasi yang sama atau konstan pada setiap tingkat pengamatan, atau disebut dengan homoskedastisitas. Sedangkan variasi residual yang tidak konstan disebut dengan heteroskedastisitas. Maka dalam uji asumsi ini diharapkan bahwa asumsi heteroskedastisitas tidak terpenuhi. Asumsi heteroskedastisitas tidak terpenuhi jika titik distribusi data residual menyebar di atas dan di bawah angka 0 pada sumbu Y. Persebaran residu berada pada atas dan bawah angka 0 pada sumbu Y maka dapat disimpulkan asumsi heteroskedastisitas tidak terpenuhi, sehingga dapat dilakukan uji regresi pada penelitian ini.

Kemudian, hasil data di atas dapat diketahui pula persamaan regresi penelitian ini. Persamaan regresi tersebut dihitung dengan menggunakan rumus persamaan regresi linier sederhana $Y=a+b X$. Maka persamaan regresi linier sederhana pada penelitian ini dapat dirumuskan $Y=5,563+0131 X$. Persamaan ini menunjukan bahwa apabila parenting self efficacy meningkat 1\%, maka nilai keterlibatan orang tua dalam karier juga meningkat sebesar 0,131.

\section{I S K U S I}

Keterlibatan orang tua memiliki pengaruh yang baik bagi karier remaja karena dapat membantu remaja memahami dengan lebih jelas tentang jenjang pendidikan, karier, dan bidang pekerjaan di masa yang akan datang. Orang tua dapat terlibat dalam karier remaja sebagai model dan konselor yang memberi informasi dan arah pilihan karier. Keterlibatan orang tua dalam karier remaja juga merupakan peran dan tanggung jawab dalam memenuhi segala kebutuhan remaja termasuk kebutuhan fisik, kebutuhan materil, emosi, dan psikologis remaja serta memberikan kesempatan seluas-luasnya dalam menempuh pendidikan serta karier remaja. Agar mampu merealisasikan tuntutan tersebut, orang tua membutuhkan self efficacy yang cukup. Menurut Ozer dan Bandura (1990) self efficacy berkaitan dengan motivasi, sumber daya kognitif, dan tindakan yang diperlukan untuk melakukan kontrol atas peristiwa diberikan. Pada orang tua, self efficacy yang dimaksud adalah parenting self efficacy. Parenting self efficacy juga merupakan salah satu aspek yang mempengaruhi keterlibatan orang tua dalam karier. Putra (2018) mengungkapkan bahwa salah satu faktor keterlibatan orang tua dalam karier adalah parenting self efficacy. Hoover-Dempsey dan Sandler (1995) mengungkapkan bahwa parenting self efficacy memiliki kontribusi yang paling signifikan terhadap keterlibatan orang tua dalam karier anak dibandingkan faktor lainnya.

Penelitian ini bertujuan untuk mengetahui pengaruh parenting self efficacy terhadap keterlibatan orang tua dalam karier remaja. Dalam penelitian ini alat ukur keterlibatan orang tua memiliki keterbatasan, sehingga keterlibatan yang dimaksud hanya mengukur pada persiapan maupun perencanaan karier remaja saja. Berdasarkan analisis data yang telah dilakukan, hipotesis diterima yang artinya terdapat pengaruh variabel parenting self efficacy terhadap variabel keterlibatan orang tua dalam karier. Hasil penelitian yang diperoleh dalam penelitian ini didukung oleh hasil penelitian yang dilakukan Putra (2018) yang menyatakan bahwa parenting self efficacy atau keyakinan melakukan yang terbaik untuk anak merupakan faktor yang berpengaruh terhadap keterlibatan orang tua dalam karier anak. Parenting self efficacy merupakan perkembangan dari pengalaman semasa hidup. Salah satu faktor yang 
membentuk parenting self efficacy adalah pengalaman orang tua (Coleman, 1998). Hasil penelitian ini dapat dijelaskan melalui karakteristik subjek.

Partisipan dalam penelitian ini adalah individu yang bekerja dan tidak bekerja serta memiliki anak dengan rentang usia mulai dari 15 hingga 24 tahun. Menurut Super (1980) usia tersebut berada pada tahap exploration, yang ditandai dengan proses dimana individu mulai mengidentifikasi secara menyeluruh terkait beberapa pilihan karier yang akan diambil. Dalam proses tersebut biasanya individu dipengaruhi oleh orang terdekat seperti teman atau keluarga. Lebih dari setengah subjek adalah orang tua yang memiliki pekerjaan. Hal ini menunjukan bahwa subjek memiliki banyak pengalaman terkait pekerjaan atau bidang karier. Pengalaman atau keadaan orang tua turut berpengaruh dalam pembentukkan sudut pandang anak. Contohnya, anak dengan orang tua yang bekerja cenderung mengetahui apa yang ingin mereka kerjakan kelak setelah lulus sekolah. Hal tersebut kemudian yang diduga menyebabkan parenting self efficacy dalam penelitian ini memberikan pengaruh signifikan terhadap keterlibatan orang tua dalam karier remaja.

Koginif orang tua juga menjadi faktor dalam perkembangan parenting selfefficacy (Coleman \& Karraker, 2005). Coleman dan Karraker (2000) menemukan bahwa parenting self efficacy berhubungan dengan beberapa komponen kesiapan kognitif dan tingkah laku dalam melakukan pengasuhan. Pendidikan yang tinggi diyakini sebagai salah satu faktor yang mempengaruhi kognitif seseorang (Coleman \& Karraker, 2005). Seseorang dengan tingkat pendidikan yang tinggi cenderung memiliki pengetahuan yang lebih luas mengenai banyak hal, termasuk karier anak. Dalam penelitian ini, penulis tidak menanyakan tingkat pendidikan orang tua dan hanya mengontrol status kerja subjek. Walaupun demikian, status pekerjaan tentu memberikan pengaruh karena hal tersebut berkaitan dengan pengalaman yang merupakan konsep utama parenting self efficacy.

Bandura (1997) menyatakan bahwa tingkat self efficacy individu menentukan seberapa banyak usaha atau kesediaaan yang dilakukan seseorang ketika menghadapi situasi tertentu. Semakin kuat self efficacy, maka usaha yang dilakukan akan semakin aktif (Antawati \& Murdiyani, 2013). Dalam hal pengasuhan, self efficacy yang dimaksud adalah parenting self efficacy. Parenting self efficacy dan keterlibatan orang tua dalam karier merupakan variabel yang saling terkait. Berdasarkan teori belajar sosial Bandura, salah satu konstruk yang membangun parenting self efficacy yaitu umpan balik verbal dari orang lain (verbal persuasion) (Coleman, 1998). Tingginya verbal persuasion dapat meningkatkan parenting self efficacy orang tua yang dibutuhkan dalam mendorong dan mendukung karier anak. Sebab, parenting self efficacy yang tinggi menandakan bahwa orang tua telah memberikan lingkungan pengasuhan yang adaptif, menstimulasi, serta menjadi faktor pendorong dalam segala aspek perkembangan anak (Donovan, Leavitt, \& Walsh, 1997). Sebaliknya, parenting self efficacy yang rendah menjadi faktor utama yang menyebabkan perilaku pengasuhan yang cenderung defensive dan controlling behavior sehingga rentan mengalami stres karena sulit memenuhi tuntutan keluarga (Antawati \& Murdiyani, 2013).

\section{S I M P U L A N}

Berdasarkan hasil penelitian, diketahui bahwa parenting self efficacy berpengaruh terhadap keterlibatan orang tua dalam karier remaja. Saran untuk penelitian selanjutnya dan para orang tua. Penelitian selanjutnya disarankan agar mengontrol variabel demografis (seperti usia subjek, jumlah anak, dan pendidikan subjek). Penelitian selanjutnya juga dapat menambahkan pembahasan perbedaan peran ibu dan ayah, budaya dan pola asuh. Kedua hal tersebut dapat memberikan dampak yang berbeda, baik terhadap remaja maupun keterlibatan orang tua dalam karier remaja (Dietrich \& Kracke, 2009). Orang tua diharapkan dapat terlibat dalam karier remaja, karena dapat bermanfaat baik pada remaja dan orang tua sendiri.

Buletin Riset Psikologi dan Kesehatan Mental (BRPKM)

2021, Vol. 1(1), 27-36 


\section{U C A P A N T E RIMAKASIH}

Penulis mengucapkan terima kasih kepada seluruh pihak yang terlibat dalam penelitian ini, terutama Ibu Dewi Retno Suminar selaku pembimbing dan Dosen Fakultas Psikologi Universitas Airlangga serta keluarga, kerabat dan teman-teman yang mendukung penulis selama ini.

\section{DEKLARASI POTENSI TERJADINYAKONFLIK KEPENTINGAN}

Ai Nuryanti Safitri tidak bekerja, menjadi konsultan, memiliki saham, atau menerima dana dari perusahaan atau organisasi manapun yang mungkin akan mengambil untung dari diterbitkannya naskah ini.

\section{PUSTAKA ACUAN}

Anastiani, A., \& Primana, L. (2019). Masihkah keterlibatan orang tua berkontribusi dalam pengambilan keputusan karier mahasiswa tingkat akhir? Jurnal Imliah Psikologi, 1(10), 51-71.

Antawati, D. I., \& Murdiyani, H. (2013). Dinamika psikologis pembentukan parenting self efficacy pada orangtua penyandang tunarungu yang memiliki anak berpendengaran normal. Jurnal Psikologi Terapan, 4(1), 31-47.

Azwar. (2004). Penyusunan Skala Psikologi. Yogyakarta: Pustaka Pelajar.

Azwar. (2012). Metode Penelitian. Yogyakarta: Pustaka Pelajar.

Bandura, A. (1997). The Exercise of Control. New York: Freeman.

Coleman. (1998). Maternal Self Efficacy Beliefs as Predictors of Parenting Competence and Toddlers Emotional, Social, and Cognitive Development. West Virginia University (Vol. 1). Morgantown: The Research Repository WVU. Retrieved from https://researchrepository.wvu.edu/etd/3118/

Coleman, P. K., \& Karraker, K. H. (1997). Self efficacy and parenting quality: Findings and future applications. Development Review, 18(1), 47-85. doi:10.1006/drev.1997.0448

Coleman, P. K., \& Karraker, K. H. (2000). Parenting self efficacy among mothers of school age children: Conceptualization, measurement, and correlates. Family Relations, 49(1), 13-24. doi:10.1111/j.1741- 3729.2000.00013

Coleman, P. K., \& Karraker, K. H. (2003). Maternal self-efficacy beliefs, competence in parenting, and toddlers' behavior and developmental status. Infant Mental Health Journal, 24(2), 126-148. doi:10.1002/imhj.10048

Coleman, P. K., \& Karraker, K. H. (2005). Parenting self efficacy beliefs and child outcomes. Contemporary Perspectives in Early Childhood Education. Retrieved September 13, 2020, from http://books.google.co.id/books?id=iTIo0IwPoLUC\&printsec=frontcover\&hl=id\&source=gbs_ge _summary_r\&cad=0\#v=onepage\&q\&f=false

Dietrich, J., \& Kracke, B. (2009). Career specific parental behaviors in adolescents development. Journal of Vocational Behavior, 75(2), 109-119. doi:10.1016/j.jvb.2009.03.005 
Donovan, W. L., Leavitt, L. A., \& Walsh, R. O. (1997). Cognitive set and coping strategy affect mothers' sensitivity to infant cries: A signal detection approach. Child Development, 68(5), 760-772. doi:10.1111/j.1467-8624.1997.tb01960.x

Eggebeen, D. J., \& Knoester, C. (2001). Does fatherhood matter for men? Journal of marriage and family, 63(2), 381-393. doi:10.1111/j.1741-3737.2001.00381.x

Grolnick, W. S., Benjet, C., Kurowski, C. O., \& Apostoleris, N. H. (1997). Predictors of parent involvement in children's schooling. Journal of Educational Psychology, 89(3), 538-548.

Harahap, N. N. (2016). Pengaruh Parenting Self Efficacy dan Kepuasan Perkawinan terhadap Keterlibatan Ayah dalam Pengasuhan. Universitas Airlangga. Surabaya: Instutional Repository Discovery Service. Retrieved from http://repository.unair.ac.id/id/eprint/46813

Hidayati, F., Kaloeti, D. V., \& Karyono. (2011). Peran ayah dalam pengasuhan anak. Jurnal Psikologi, 9(1), 1-10. doi:doi.org/10.14710/jpu.9.1

Hidayati, Z. (2010). Anak Saya Tidak Nakal. Yogyakarta: PT Bintang Pustaka.

Hoover-Dempsey, K. V., \& Sandler, H. M. (1995). Parental involvement in children's education: Why does it make a difference? American Journal of Educational Research, 97(2), 310-331.

Hoover-Dempsey, K. V., Walker, J. M., Sandler, H. M., Whetsel, D., Green, C. L., Wilkins, A. S., \& Closson, K. (2005). Why do parents become involved? Research findings and implications. The elementary school journal, 106(2), 105-130.

Joseph, L. L. (2012). The Impact of Family Influence and Involvement on Career Development. Doctoral Thesis and Dissertation. Florida: University of Central Florida. Retrieved from http://etd.fcla.edu/CF/CFE0004391/Latashia_Joseph_Dissertation_Chapters_15_07202012FINAL.pdf

Mortimer, J. T., Zimmer-Gembeck, M. J., Holmes, M., \& Shanahan, M. J. (2002). The process of occupational decision making: Patterns during the transition to adulthood. Journal of Vocational Behavior, 61(3), 439-465.

Neuman, L. W. (2000). Social Research Methods: Qualitative and Quantitative Approaches. Boston: Allyn \& Bacon.

Otto, L. B. (2000). Youth perspectives on parental career influence. Journal of Career Development, 27(2), 111-118.

Ozer, E. M., \& Bandura, A. (1990). Mechanism governing empowerment effects: Self-efficacy analysis. Journal of Personality and Social Psychology, 472-486.

Pleck, J. H. (1997). Paternal Involvement: Levels, Sources, and Consequences. American Psychological Association. Washington, DC: APA PsycNet. Retrieved from https://psycnet.apa.org/record/1996-06350-004

Putra, A. K. (2018). Keterlibatan orang tua dalam perencanaan karir anak usia SMP di Dusun Jamburejo. Jurnal Riset Mahasiswa Bimbingan dan Konseling, 9(4), 501-511.

Buletin Riset Psikologi dan Kesehatan Mental (BRPKM)

2021, Vol. 1(1), 27-36 
Setiawan, S. R. (2017, April 3). Sri mulyani: Peran orang tua indonesia dalam pendidikan masih minim. Kompas. $\quad$ Retrieved Desember 26, 2020, from https://money.kompas.com/read/2017/04/03/073000926/sri.mulyani.peran.orang.tua.indone sia.dalam.pendidikan.masih.minim?page=all

Simon, B. S. (2004). High school outreach and family involvement. Social Psychology of Education, 7(2), 185-209.

Sugiyono. (2013). Metode Penelitian Kuantitatif, Kualitatif dan R\&D. Bandung: Alfabeta.

Super, D. E. (1980). A life-span, life-space approach to career development. Journal of vocational behavior, 16(3), 282-298.

Suryanto, B. (1995). Metode Penelitian Sosial. Surabaya: AUP.

Witko, K., Bernes, K. B., Magnusson, K., \& Bardick, A. D. (2005). Senior high school career planning: What students want. The Journal of Educational Inquary, 6(1), 34-49.

Wulandari, R., Zaini, A., \& Chandra, Y. (2017). Peran orangtua dalam mempersiapkan karir remaja di jorong rimbo tangah kecamatan sangir kabupaten solok selatan. Bimbingan dan Konseling. Padang: STKIP PGRI Sumatera Barat. 